Creative Commons User License: CC BY-NC-ND

Abstracted by: EBSCOhost, Electronic Journals Service (EJS),

Google Scholar, Journal Seek, Scientific Commons,

Food and Agricultural Organization (FAO), CABI and Scopus

http://eoi.citefactor.org/10.11226/v23i1
Journal of Agricultural Extension

Vol. 23 (1) January, 2019

ISSN(e): 24086851; ISSN(Print); 1119944X

http://journal.aesonnigeria.org

http://www.ajol.info/index.php/jae

Email: editorinchief@aesonnigeria.org

\title{
Strategies Use by Smoked Fish Marketers in Kainji Lake Basin, Nigeria
}

https://dx.doi.org/10.4314/jae.v23i1.5

\section{Nwabeze, Godfrey Onyekachukwu*}

Extension Programme, National Institute for Freshwater Fisheries Research (NIFFR), P.M.B. 6006, New Bussa, Nigeria

Email: onyegodfrey@yahoo.com

Phone: +2348052923218

\section{Faleke, Sunday}

Extension Programme, National Institute for Freshwater Fisheries Research (NIFFR), P.M.B. 6006, New Bussa, Nigeria

Email: falekesunday12@gmail.com

Phone: +23408052923218

\section{Tanko, Mohammed}

Extension Programme, National Institute for Freshwater Fisheries Research (NIFFR), P.M.B. 6006, New Bussa, Nigeria

Email: tkahmed1138@gmail.com

Phone: +2348097477220

\section{Malgwi, Yakubu Yamata}

Department of Agricultural Economics \& Extension, Adamawa State University, P.M.B 25,

Mubi, Nigeria

Email: yakubu.malgwi15@gmail.com

Phone: +2347034724375

${ }^{*}$ Corresponding Author

\section{Abstract}

This study examined strategies use by smoked fish marketers in Kainji Lake Basin, Nigeria. Multistage sampling procedure was used to select forty-six respondents. Semi-structured interview schedule was employed for data collection. Data were analysed using percentages, mean and standard deviation. The study reveals that $80.4 \%$ of the respondents were male, with $48.1 \%$ within the age bracket 41 and 45 years with mean age of 45 years. Many of the respondents were literate (89.7\%) and married (94.5\%). The study identified commissioned agents as the main marketing channels in the area. Creating effective point of fish sale (3.94 \pm 0.83 ), use of ICT (GSM) to reach customers (3.92 \pm 0.97 ), establishment of good reputation (3.90 \pm 0.52$)$, increase access to market information (3.87 \pm 0.67$)$ were the leading marketing strategies adopted by the smoked fish marketers. Challenges faced by the respondents included inadequate financial resources (3.96 \pm 0.84$)$, weak extension service

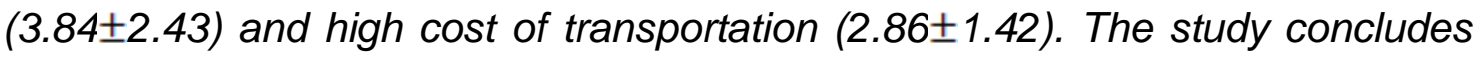
that the limitations to smoked fish marketing were related to policy issues and infrastructure in terms of access to financial resources, efficient means of 
Creative Commons User License: CC BY-NC-ND

Abstracted by: EBSCOhost, Electronic Journals Service (EJS),

Google Scholar, Journal Seek, Scientific Commons,

Food and Agricultural Organization (FAO), CABI and Scopus

http://eoi.citefactor.org/10.11226/v23i1
Journal of Agricultural Extension

Vol. 23 (1) January, 2019

ISSN(e): 24086851; ISSN(Print); 1119944X

http://journal.aesonnigeria.org

http://www.ajol.info/index.php/iae

Email: editorinchief@aesonnigeria.org

transportation and extension service delivery Therefore, it is recommended that smoked fish marketers group be registered as cooperative to facilitate vibrant extension service for effective linkage of fish smoked marketers with credit sources and also provide market support in the area.

Keywords: Fish marketing, smoked fish, Kainji lake basin

\section{Introduction}

Availability of fish to consumers at the right time and in the right place requires an effective marketing system (Department of Fisheries, 2012). Fish marketing is beyond advertising, selling or making fish available to consumers. It is a key management that brings success to the business. Success of fish marketing largely depends on how efficiently the products and services are delivered to consumers and how differently do the consumers perceive the difference in delivery in comparison to the competitors. Fish marketing becomes profitable only when the products are delivered in a wholesome condition and at a price acceptable to the consumers (Nwabunike, 2014)

Marketing strategies however, is all encompassing and involves identifies consumer's needs, effective channels to reach them, ensures consumer's satisfaction and ensures profit maximization. Fish marketing plays a vital role in the lives of much of the lake basin's population, both in terms of employment and nutrition. Babalola, Bamiji and Isitor (2015) indicated that fish marketing provided increased income to many Nigerians who distribute fresh and processed fish across the country. Kainji Lake Basin has not been left out in ensuring that fish marketing develops to bridge the gap as a source of alternative livelihood to the local communities (Michael, 2014). It has been perceived to be both social and economic activity of the households' and communities around Kainji Lake Basin shortly after the impoundment of the River Niger (1966-1967). Fish marketing is almost entirely a function of the private sector and operates through a system of village markets, township markets, assembly centres, retail markets and urban wholesale (Department of Fisheries, 2012). It is not usually on the basis of fishermen - consumer, therefore prices of fish change as it passes through middlemen such that by the time it reaches consumers it becomes expensive (Amin, Islam and Hossain, 2012). Most of the time fishermen are compelled to hand over their catches to the middlemen at a price determined by the latter. These middlemen are not just a trader in fish. Most of them are fishermen owning and operating ponds, boat, gear, employing other fishermen on a fixed wage as hired labourers and enjoying unearned income depriving the actual fishermen of the benefit of their labour and production (Rahman et al., 2012). Lack of appropriate marketing strategies, skills and knowledge in marketing had further complicated the situation leaving many fish farmers and fishers struggling to grow market share. As sustainability of fisheries production largely depends on the producers receiving sufficient income. Determining the prices and margins that occur in the fish marketing channel will contribute to the determination of policies that will prevent the decrease in the producer income that should be applied in the sector (Aswathy, Narayanakumar and Harshan, 2014). Therefore, for the fisheries activity to be profitable, a suitable distribution channel must be selected to ensure that the conditions under which fish and other aquatic resource are to be handled are met on time and with minimal expense. From the perspective of the part of the consumer, fish accounts for $40 \%$ of protein dietary 
Creative Commons User License: CC BY-NC-ND

Abstracted by: EBSCOhost, Electronic Journals Service (EJS),

Google Scholar, Journal Seek, Scientific Commons,

Food and Agricultural Organization (FAO), CABI and Scopus
Journal of Agricultural Extension

Vol. 23 (1) January, 2019

ISSN(e): 24086851; ISSN(Print); 1119944X

http://journal.aesonnigeria.org

http://www.ajol.info/index.php/iae

Email: editorinchief@aesonnigeria.org

intake in Nigeria and to as high as $80 \%$ in inland and coastal communities (Ozigbo et al., 2014; Adebayo et al., 2014). Thus, fish market contributes significantly to the livelihoods and food/nutrition security of communities around Kainji lake basin. Regrettably, not much research has been carried out to verify marketing strategies of smoked fish marketers in Kainji Lake Basin, Nigeria hence, the need for this study. The study is an endeavour to fill the research gap and contribute to the generation of empirical evidence for policy guidance on smoked fish marketing in Kainji Lake Basin, Nigeria. It is against this background that this study analyzed strategies use by smoked fish marketers in Kainji Lake Basin, Nigeria.

\section{Objectives of the Study}

The broad objective of this study was to make available empirical information on strategies use by smoked fish marketers in Kainji Lake Basin, Nigeria. Specifically, the study was designed to:

- determine the volume and value of smoked fish marketed in the study area.

- identify smoked fish marketing channels in the study area

- examine smoked fish marketing strategies adopted by the marketers.

- identify the challenges in fish marketing in the study area

- examine respondents' assessment of sources of smoked fish

\section{Methodology}

The study was carried out in communities in the Kainji Lake Basin, Nigeria. Kainji Lake represents the second most important inland fisheries source in Nigeria. The lake is formed by the damming of River Niger in 1968. The lake cut across Kebbi and Niger States. Multistage sampling procedure was used for the study. The first stage was the stratification of major smoked fish marketing centres within the lake basin into 5 centres (New Bussa, Yauri, Shagunu, Wara and Kokoli). The second stage was the purposive selection of New Bussa due to large number of smoked fish marketers in the area. Selection of identified communities actively involved in distant smoked fish marketing in New Bussa centre formed the third stage. Thus; communities in New Bussa centre included New Bussa, Monai, Fakun, Awuru, Malale, Nasarawa, and Guffanti. The fourth step was selection of all distant smoked fish marketers from the list of registered members in New Bussa centre. Thus, a total of 46 smoked fish marketers were interviewed.

The variables studied were; volume and value of smoked fish marketed, channels for smoked fish marketing, fish marketing strategies, challenges in fish marketing and respondents' assessment of sources of smoked fish. Field survey was carried out using interview schedule method to obtain needed primary data. The survey took place between 2016 and 2017. Market information on quantity, price and destination was collected. Data collected were analysed using descriptive statistics involving the use of tables, percentages, frequency, mean and standard deviation.

Information on the socio-economic characteristics of the respondents was examined. Respondents were asked to indicate their sex, marital status, age (years), educational level, experience in fish marketing and sources of finance. 
Creative Commons User License: CC BY-NC-ND

Abstracted by: EBSCOhost, Electronic Journals Service (EJS),

Google Scholar, Journal Seek, Scientific Commons,

Food and Agricultural Organization (FAO), CABI and Scopus

http://eoi.citefactor.org/10.11226/v23i1
Journal of Agricultural Extension

Vol. 23 (1) January, 2019

ISSN(e): 24086851; ISSN(Print); 1119944X

http://journal.aesonnigeria.org

http://www.ajol.info/index.php/iae

Email: editorinchief@aesonnigeria.org

To examine sources of smoked fish, respondents were asked to specify whether the smoked fish were captured or cultured.

To find out the marketing strategies adopted by the smoked fish marketers a list of variables on marketing strategies was prearranged on a 4-point Likert type scale with response options of strongly agree $=4$, agree $=3$, disagree $=2$ and strongly disagree $=1$. Likewise, possible challenges on smoked fish marketing was also rated on four point Likert scale of very serious $=4$, serious $=3$, little serious $=2$ and not serious $=1$. The values on the Likert scale were added to obtain 12 which were divided by 4 to obtain 2.5 . Any value with mean score equal or greater than 2.5 was considered positive.

To determine the volume and value of smoked fish marketed in the area, the cartons of the processed fish were classified as small, medium and large measuring $<50,000 \mathrm{~cm}^{3}$, $50,001 \mathrm{~cm}^{3}-99,000 \mathrm{~cm}^{3}$ and $100,000 \mathrm{~cm}^{3}$ and above respectively. Similarly, average weights per price of the classified cartons of processed fish were taken weekly and multiplied by the total number of cartons.

\section{Results and Discussion}

\section{Socio-economic Characteristics of the Respondents}

Table 1 shows that the majority $(80.4 \%)$ of the smoked fish marketers were male, with $48.1 \%$ within the age bracket $41-45$ years and mean age of 45 years. The majority $(89.7 \%)$ of the respondents had one form of education or the other led by those with Primary and University education representing $41.5 \%$ and $31.0 \%$ respectively. This implies that smoked fish marketing and trade is dominated by literate class. This implies that the smoked fish marketer will be more receptive to accepting the innovation in fish marketing and trade. Respondents' years of marketing experience indicates that scores $(48.1 \%)$ of them had 41 45 years. Their mean years of experience in smoked fish marketing were about 17.0 years. The findings suggest that the smoked fish marketing has been age trade of the respondents. Majority $(80.2 \%)$ of the respondents financed their smoked fish marketing through personal funds. This finding agrees with the assertion of Nwabeze et al., (2017) that personal savings constitute the main source of fund for sustaining fisheries enterprise in Kainji Lake Basin, Nigeria. 
Creative Commons User License: CC BY-NC-ND

Abstracted by: EBSCOhost, Electronic Journals Service (EJS),

Google Scholar, Journal Seek, Scientific Commons,

Food and Agricultural Organization (FAO), CABI and Scopus

http://eoi.citefactor.org/10.11226/v23i1
Journal of Agricultural Extension

Vol. 23 (1) January, 2019

ISSN(e): 24086851; ISSN(Print); 1119944X

http://journal.aesonnigeria.org

http://www.ajol.info/index.php/jae

Email: editorinchief@aesonnigeria.org

Table 1: Socio-economic characteristics of respondents

\begin{tabular}{|c|c|c|c|}
\hline $\begin{array}{l}\text { Variable } \\
\text { ] }\end{array}$ & Categories & $\begin{array}{c}\text { Percentage }^{*} \\
(n=46)\end{array}$ & Mean \\
\hline Sex & $\begin{array}{l}\text { Male } \\
\text { Female }\end{array}$ & $\begin{array}{l}80.4 \\
19.6\end{array}$ & \\
\hline Marital status & $\begin{array}{l}\text { Married } \\
\text { Single }\end{array}$ & $\begin{array}{r}94.5 \\
5.5\end{array}$ & \\
\hline Age & $\begin{array}{l}<35 \\
36-40 \\
41-45 \\
46-50 \\
51 \text { and above }\end{array}$ & $\begin{array}{c}10.2 \\
19.0 \\
48.1 \\
15.7 \\
7.0\end{array}$ & 44.5 \\
\hline Educational level & $\begin{array}{l}\text { University } \\
\text { Polytechnic } \\
\text { Secondary } \\
\text { Primary } \\
\text { No formal education }\end{array}$ & $\begin{array}{r}31.0 \\
13.8 \\
3.4 \\
41.5 \\
10.3\end{array}$ & \\
\hline Experience in fish marketing & $\begin{array}{l}<10 \\
11-15 \\
16-20 \\
21 \text { and above }\end{array}$ & $\begin{array}{l}14.1 \\
21.5 \\
40.2 \\
20.1\end{array}$ & 17.2 \\
\hline Sources of finance & $\begin{array}{l}\text { Personal savings } \\
\text { Cooperative society }\end{array}$ & $\begin{array}{l}80.2 \\
19.8\end{array}$ & \\
\hline
\end{tabular}

Source: Field survey, 2016/2017

\section{Volume of Smoked Fish Marketed}

The volume of smoked fish traded in the study area in year 2016 to 2017 is presented in Figure 1. The average annual volume of smoked fish marketed in area was 281.8 tonnes in year 2016 and 313.2 tonnes in year 2017. The average monthly volume of smoked fish was 23.3 tonnes and 26.1 tonnes for year 2016 and 2017 , respectively. The peak monthly volume of smoked fish traded in year 2016 was $45.8 \pm 3.6$ tonnes in December and in the year 2017, $40.8 \pm 11.1$ tonnes in the month of April. The lowest monthly volume was $15.6 \pm 4.9$ tonnes and 15.3 \pm 11.8 in May for year 2016 and 2017 in that order. 
Creative Commons User License: CC BY-NC-ND

Abstracted by: EBSCOhost, Electronic Journals Service (EJS),

Google Scholar, Journal Seek, Scientific Commons,

Food and Agricultural Organization (FAO), CABI and Scopus

http://eoi.citefactor.org/10.11226/v23i1

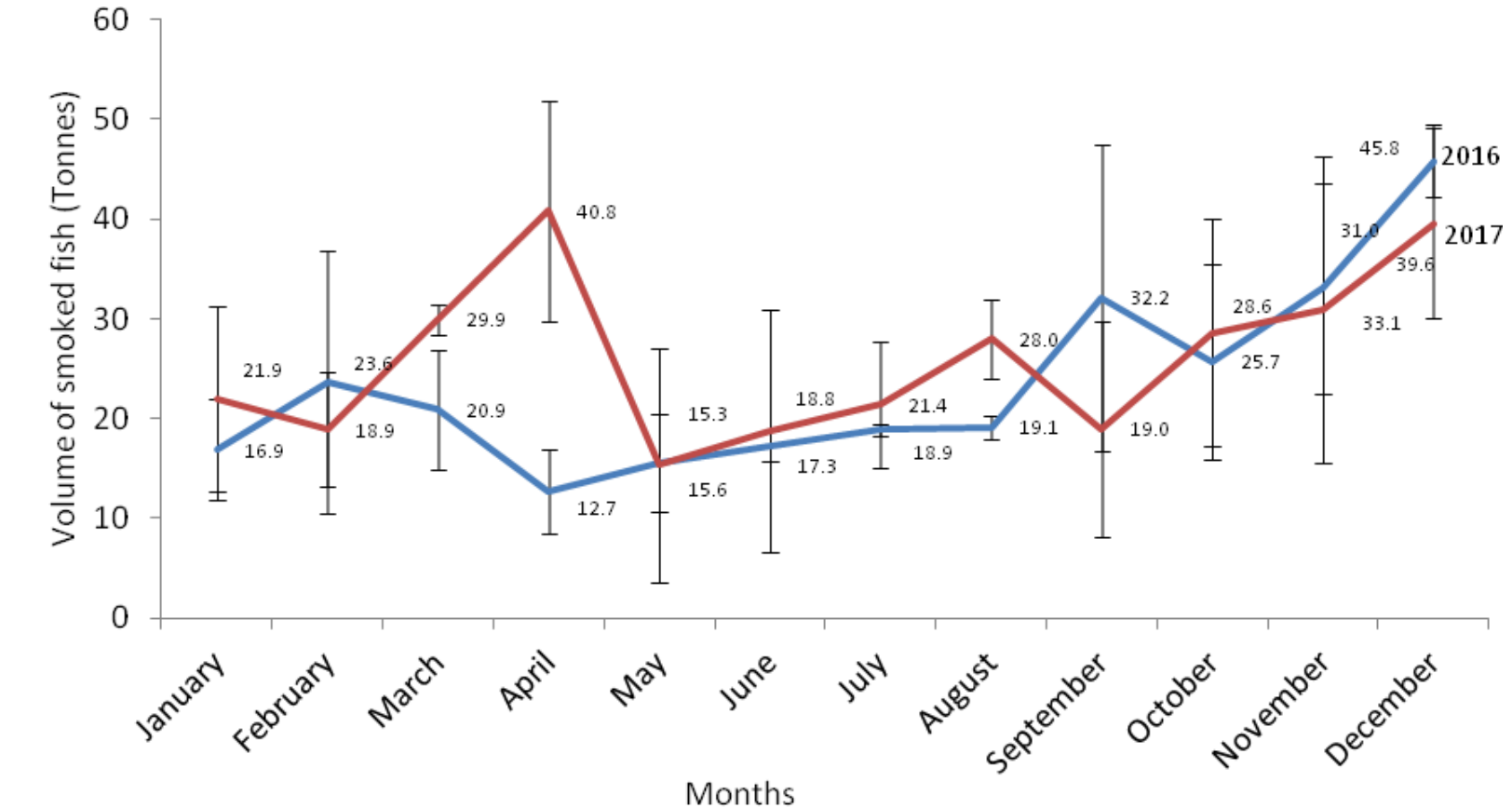

Journal of Agricultural Extension Vol. 23 (1) January, 2019

ISSN(e): 24086851; ISSN(Print); 1119944X

http://journal.aesonnigeria.org

http://www.ajol.info/index.php/iae

Email: editorinchief@aesonnigeria.org

Figure 1: Volume of smoked fish transported and marketed outside New Bussa in Year 2016 and 2017 Source: Field survey, 2016/2017

\section{Respondents Assessment of Sources of Smoked Fish}

Figure 2 shows respondents' assessment of sources of their traded smoked fish. It reveals that $63.0 \%$ and $37.0 \%$ of the smoked fish marketed in year 2016 was from pond culture system and wild capture, respectively. This marginally increased to $65.2 \%$ and $34.8 \%$ in year 2017. The finding connotes that smoked fish marketers rely greatly on culture fish. This reflected on pattern of the monthly volume of smoked fish marketed in the area. The finding further indicates that increasing decline in capture fisheries of the Kainji lake basin paved way to the growing expansion of cultured fish business in the area which has supported huge smoked fish marketing. 
Creative Commons User License: CC BY-NC-ND

Abstracted by: EBSCOhost, Electronic Journals Service (EJS),

Google Scholar, Journal Seek, Scientific Commons,

Food and Agricultural Organization (FAO), CABI and Scopus

http://eoi.citefactor.org/10.11226/v23i1

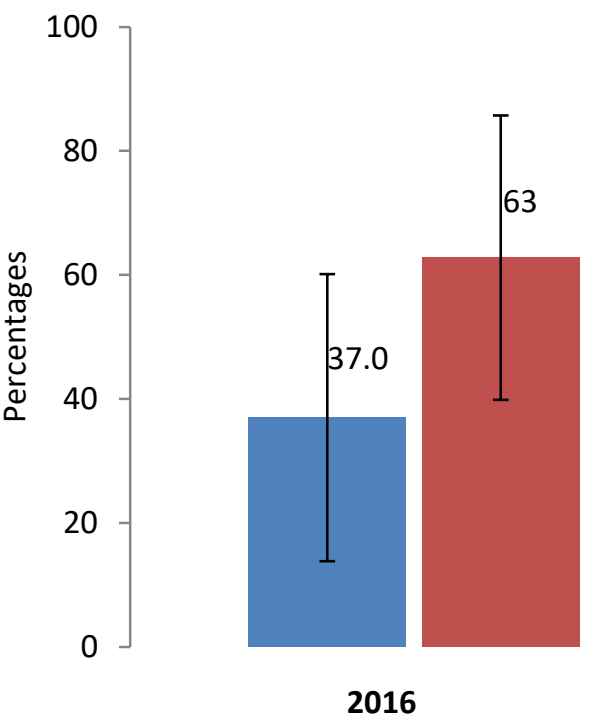

Journal of Agricultural Extension

Vol. 23 (1) January, 2019

ISSN(e): 24086851; ISSN(Print); 1119944X

http://journal.aesonnigeria.org

http://www.ajol.info/index.php/iae

Email: editorinchief@aesonnigeria.org

Years

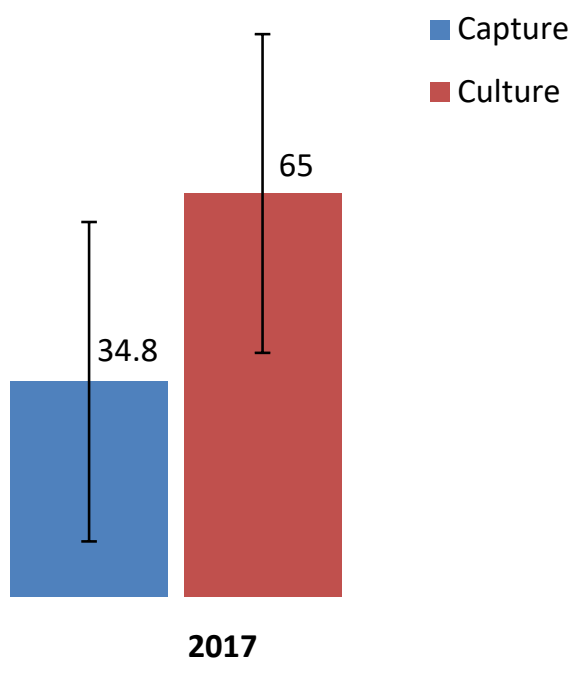

Figure 2: Respondents' assessment of sources of smoked fish

Source: Field survey, 2016/2017

\section{Value of Fish Marketed in the Study Area}

The monetary value of smoked fish marketed in the area is shown in Figure 3. The average annual monetary value of smoked fish marketed in area was $\$ 476,931,941.67$ in year 2016 and $\$ 530,494,625.00$ in year 2017 representing 89.9 percent increase. The average monthly monetary value of smoked fish traded was $\$ 39,744,328.47$ and $\$ 44,207,885.42$ for year 2016 and 2017 correspondingly. The maximum monthly value of smoked fish traded in year 2016 and 2017 was $\$ 63,639,666.67 \pm 7,259,461.50$ and $\$ 69,378,750.00 \pm 22,805,962.81$ in the month of December and the lowest was $\$ 25,116,400.00 \pm 5,911,363.58$ in year 2016 and $24,963,500.00 \pm 23,283,108.48$ in 2017 for the month of April and May respectively. The finding implies that the value for smoked fish was more during festive period (December 2016 / 2017 and April, 2017) justifying increased market demand. The low value recorded in April, 2016 could be attributed to economic downturn experienced in the country within the period. According to Asche (2018), fish is the most heavily traded food commodity in the international market. In Nigeria, demand for has been reported to be doubling as other sources of animal protein become expensive due to the ever increasing human population and high production cost of other protein cost (Yusuf, 2012). 
Creative Commons User License: CC BY-NC-ND

Abstracted by: EBSCOhost, Electronic Journals Service (EJS),

Google Scholar, Journal Seek, Scientific Commons,

Food and Agricultural Organization (FAO), CABI and Scopus

http://eoi.citefactor.org/10.11226/v23i1

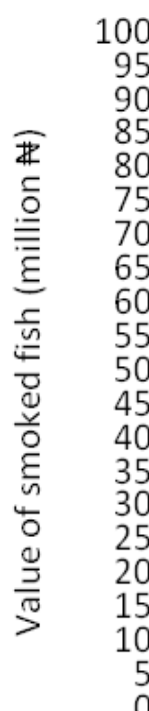

Journal of Agricultural Extension

Vol. 23 (1) January, 2019

ISSN(e): 24086851; ISSN(Print); 1119944X

http://journal.aesonnigeria.org

http://www.ajol.info/index.php/iae

Email: editorinchief@aesonnigeria.org

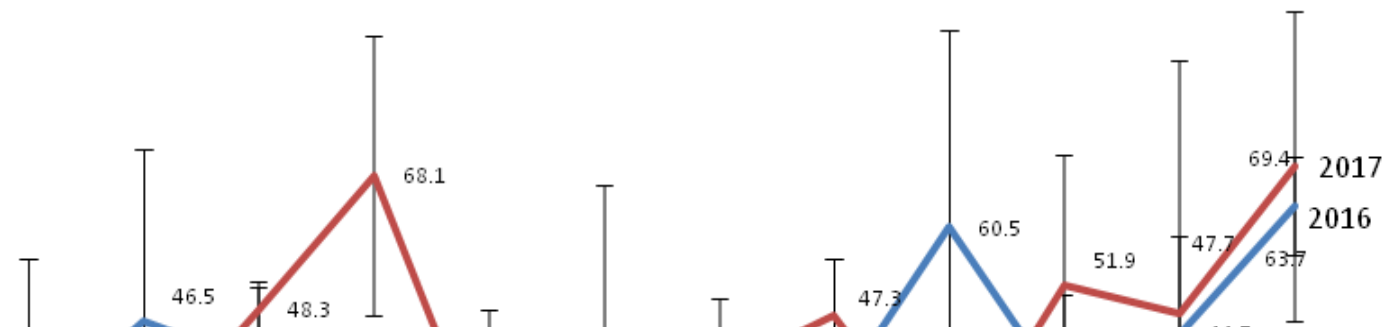

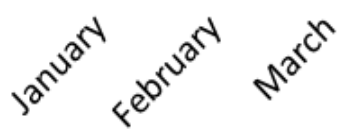

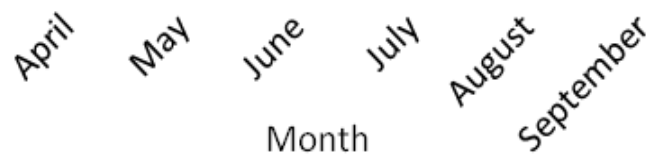

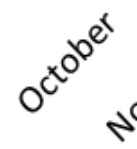

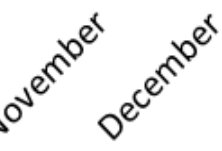

Figure 3: Value of smoked fish transported and marketed outside New Bussa in Year 2016 and 2017 Source: Field survey, 2016/2017

\section{Marketing Channels for Smoked Fish}

Smoked fish marketers in the study area buy unprocessed (fresh) farmed fish from smallholder farmers/fishers directly within the local community. The processed and packaged smoked fish were transported to distant market and received by commissioned agents. The marketers' target distant smoked fish marketing points in large urban centres of south-east (Onitsha) and south-south (Agbor and Warri), Nigeria for more profit. The channel for distant smoked fish marketing is presented in Fig 4. The smoked fish are transferred to fish traders in the marketing points through commissioned agents. The agents sell directly to fish traders who finally sell to the consumers. 
Creative Commons User License: CC BY-NC-ND

Abstracted by: EBSCOhost, Electronic Journals Service (EJS),

Google Scholar, Journal Seek, Scientific Commons,

Food and Agricultural Organization (FAO), CABI and Scopus
Journal of Agricultural Extension

Vol. 23 (1) January, 2019

ISSN(e): 24086851; ISSN(Print); 1119944X

http://journal.aesonnigeria.org

http://www.ajol.info/index.php/iae

Email: editorinchief@aesonnigeria.org

http://eoi.citefactor.org/10.11226/v23i1

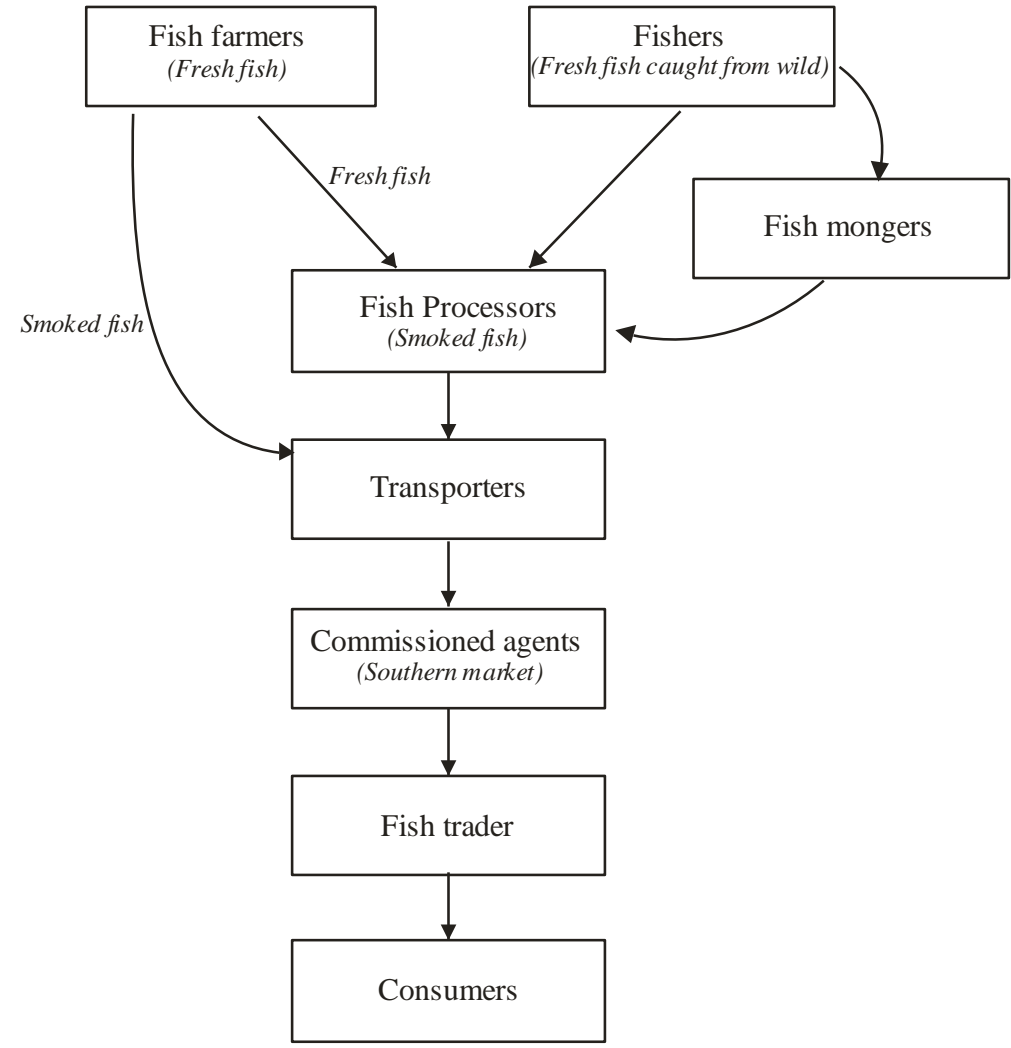

Figure 4: Distant marketing channel for smoked fish in Kainji Lake Basin

\section{Smoked Fish Marketing Strategies}

Table 2 shows marketing strategies adopted by the smoked fish marketers in the area. It reveals that the smoked fish marketers have developed marketing strategies which is led by creating effective point of fish sale (3.94 \pm 0.83$)$, use of ICT (GSM) to reach market (3.92 \pm 0.97$)$ and establishment of good reputation (3.90 \pm 0.67$)$ among others. Increasing marketing strategies by the fish marketers has been found to improves marketing efficiency in Kainji Lake Basin (Nwabeze and Madu, 2016) 
Creative Commons User License: CC BY-NC-ND

Abstracted by: EBSCOhost, Electronic Journals Service (EJS),

Google Scholar, Journal Seek, Scientific Commons,

Food and Agricultural Organization (FAO), CABI and Scopus

http://eoi.citefactor.org/10.11226/v23i1
Journal of Agricultural Extension

Vol. 23 (1) January, 2019

ISSN(e): 24086851; ISSN(Print); 1119944X

http://journal.aesonnigeria.org

http://www.ajol.info/index.php/iae

Email: editorinchief@aesonnigeria.org

Table 2: Fish marketing strategies

\begin{tabular}{lcc}
\hline \multicolumn{1}{c}{ Marketing strategies } & Mean $^{*}$ & SD \\
\hline Creating effective point of fish sale & 3.94 & 0.83 \\
Use of ICT (GSM) to reach market & 3.92 & 0.97 \\
Establish a good reputation & 3.90 & 0.52 \\
Increase access to market information & 3.87 & 0.67 \\
Target diverse class of consumers by their needs & 3.76 & $0-29$ \\
Membership of marketing group & 2.65 & 0.52 \\
Effective pricing system & 2.64 & 0.89 \\
Adopt processing technologies that allow improve fish product & 2.56 & 1.34 \\
quality & & \\
Efficient accounting system & 2.53 & 0.87 \\
Feed back on consumer feeling about my fish product & 2.42 & 1.56 \\
\hline
\end{tabular}

Source: Field survey, 2016/2017; Agreed (mean $\geq 2.50$ ); SD=Standard deviation

\section{Challenges Faced by Smoked Fish Marketers}

Challenges encountered by the smoked fish marketers are presented in Table 3. The data shows that the smoked fish marketers agreed to inadequate financial resources $(3.96 \pm 0.84)$, high cost of transportation $(2.86 \pm 1.42)$ and weak extension services $(3.84 \pm 2.43)$ as challenges confronting smoked fish marketers in the study area. The challenges faced by the respondents are related to institutional inefficiency resulting in marketers inaccessibly to financial institution, increased cost of fish transportation and low performance of extension agents. The finding collaborates study report of Agbebi (2012) that those in fisheries business have not felt the impact of extension in Ekiti state.

Table 3: Distribution of fish marketers by challenges in marketing smoked fish

\begin{tabular}{llc}
\hline Challenges & Mean & Std Deviation \\
\hline Inadequate financial resources & $3.96^{*}$ & 0.84 \\
High cost of transportation & $2.86^{*}$ & 1.42 \\
Weak extension services & $3.84^{*}$ & 2.43 \\
Poor coordination of fish marketers & 2.43 & 0.73 \\
Inadequate local markets & 2.31 & 0.45 \\
Inadequate marketing information & 2.41 & 0.54 \\
\hline
\end{tabular}

Source: Field survey, 2016/2017; Agreed (mean $\geq 2.50$ )

\section{Conclusion and Recommendations}

The study concluded that the marketers' target distant smoked fish marketing points in large urban centres of south-east (Onitsha) and south-south (Agbor and Warri), Nigeria for more profit. The limitations to smoked fish marketing were related to policy issues and infrastructure in terms of access to financial resources, efficient means of transportation and extension service delivery. It was recommended the respondents require information from extension on access to credit facility and improved extension role in service delivery. The smoked fish marketers group should be registered as cooperative and be proactive to facilitate vibrant extension service for effective linkage of fish smoked marketers with credit sources and also provide market support in the area. 
Creative Commons User License: CC BY-NC-ND

Abstracted by: EBSCOhost, Electronic Journals Service (EJS),

Google Scholar, Journal Seek, Scientific Commons,

Food and Agricultural Organization (FAO), CABI and Scopus

http://eoi.citefactor.org/10.11226/v23i1
Journal of Agricultural Extension

Vol. 23 (1) January, 2019

ISSN(e): 24086851; ISSN(Print); 1119944X

http://journal.aesonnigeria.org

http://www.ajol.info/index.php/iae

Email: editorinchief@aesonnigeria.org

\section{Acknowledgement}

The financial support from NIFFR towards this research is acknowledged. Similarly, the data collection support of the research team from Socio-Economics and Extension Services

Division, NIFFR particularly Bello, S.G is acknowledged.

\section{References}

Adebayo, E.F., Anyanwu, S.O., Ikenwachukwu, N and Onyia, L.U. (2014). Economics fish harvesting in Nigeria: a case study of Yola North Local Government Area of Adamawa State. IIFT Australia Conference Proceedings.

Agbebi, F.O (2012). Assessment of the impact of extension services on fish farming Ekiti state, Nigeria. Asian Journal of Agricultural and Rural Development. Vol 2(1), Pp 67-68

Amin, M.A., Islam, M.R. and Hossain, M.B (2012). Marketing Channel of Dried Marine Fish in the South-eastern Coastal Belt of Bangladesh. Middle-East. Journal of Scientific Research 12 (3): 301-306 and Ighoro, A (2017). Information needs of fish-feed entrepreneurs in Kainji Lake

Asche, F. (2018). Impacts of climate change on the production and trade of fish and fishery products. OCO 2018 Background Paper, Rome, FAO

Aswathy, N., Narayanakumar, R and Harshan, N.K. (2014). Marketing costs, margings and efficiency of domestic marine fish marketing in Korala. India Journal Fish 61(2), P. 97-102

Babalola, D.A, Bamiji, O and Isitor, S.U (2015). Economic potentials of fish marketing and women empowerment in Nigeria. Evidence from Ogun state. Africa Journal of Food, Agriculture, Nutrition and Development. Vol 15 no. 2, p.27

Department of Fisheries (2012). Fish Fortnight Compendium. Department of Fisheries, Ministry of Fisheries and Livestock. Government of Peoples Republic of Bangladesh, p.131

Michael, K. M. (2014). Marketing strategies of commercial fish farming under economic stimulus programme (esp) in Kenya: a case of Kitui county. A Research Project Submitted in Partial Fulfilment of the Requirements for the Award of the Degree of Master of Business Administration of Kenyatta University

Nwabeze, G.O, Ibeun, B.A, Faleke, S, Omeje, J.E, Belonwu, N.E, Igene, C.A, Nwanjoku, V.A and Ighoro, A (2017). Information needs of fish-feed entrepreneurs in Kainji Lake Basin, Nigeria. Journal of Agricultural Extension Vol.21 (3), Pp 46-55

Nwabeze, G.O and Madu, C.T (2016). Marketing of fish. In C.T Madu (ed) Fish Farming-The Value Chain Approach. Federal College of Freshwater 
Creative Commons User License: CC BY-NC-ND

Abstracted by: EBSCOhost, Electronic Journals Service (EJS),

Google Scholar, Journal Seek, Scientific Commons,

Food and Agricultural Organization (FAO), CABI and Scopus

http://eoi.citefactor.org/10.11226/v23i1
Journal of Agricultural Extension

Vol. 23 (1) January, 2019

ISSN(e): 24086851; ISSN(Print); 1119944X

http://journal.aesonnigeria.org

http://www.ajol.info/index.php/jae

Email: editorinchief@aesonnigeria.org

Fisheries Technology, New Bussa, Niger State, Nigeria. Pp 229-239

Nwabunike, M.O. (2015). Cost Benefit of Fresh Fish Marketing within Abakaliki Metropolis. International Journal of Animal Health and Livestock Production Research. Vol. 1(1), pp 12-27.

Ozigbo. E., Anyadike. C., Adegbite. O and Kolawole. P (2014). Review of aquaculture production and Management in Nigeria. America journal of Experimental Agriculture, 4(10): 1137-1151.

Rahman, M.M., Hossain, M.A., Fatematuzzhura, S., Tasnoova, F. Ahamed, M.Y. Hossain and Ohtomi, J (2012). Fresh Fish Marketing Status in the Northwestern Bangladesh: Recommendations for Sustainable Management. Our Nature 10 (1): 128-136

Yusuf, O. I. S (2012). A System Analysis of the Demand for Animal Protein in Rural and Urban Nigeria. A Case Study of Ibadan Metropolis. JORIND 10 (2), June, 2012. ISSN $1596-8308$ 